\title{
REFERENCE FLAW SIZE FOR STRUCTURAL AND FRACTURE ANALYSIS OF TYPES I AND II WASTE TANKS (U)
}

\author{
B. J. WIERSMA \\ SAVANNAH RIVER TECHNOLOGY CENTER \\ Equipment \& Materials Technology Department \\ Materials Technology Section
}

\author{
R. L. SINDELAR \\ SAVANNAH RIVER TECHNOLOGY CENTER \\ Equipment \& Materials Technology Department \\ Materials Technology Section
}

Publication Date: January, 1994

\section{Westinghouse Savannah River Company Savannah River Site Alken, SC 29808}

This document was prepared in connection with work done under Contract No. DE-AC09-89SR 18035 with the U. S. Department of Energy. By acceptance of this document, the publisher and/or recipient acknowledges the U. S. Govemment's right to retain a nonexclusive, royalty-free license in and to any copyright covering this document, along with the right to reproduce and authorize others to reproduce all or part of the copvrighted material. 


\section{DISCLAIMER}

This report was prepared by Westinghouse Sovannah River Company (WSRC) for the United States Department of Energy under Centract No. DE-ACO989SR 18035 and is an account of work performed under that contract. Nelther the United States Department of Energy, nor WSRC, nor any of their employees makes any warranty, expressed or implied, or assumes any legal liability or responsibility for the accuracy, completeness, or usefulness, of any information, apparatus, or product or process disclosed herein or represents that its use will nof infringe privately owned rights. Reference herein to any spectic commercial product, process, or service by trademark, name, manufacturer or otherwise does not necessarily constilute or imply endorsement, recommendation, or fovoring of same by WSRC or by the United Siates Govemment or any agency thereof. The views and opinions of the cuthors expressed herein do not necessarily state or reflect those of the United States Government or any agency thereof. 
REFERENCE FLAW SIZE FOR STRUCTURAL AND FRACTURE ANALYSIS OF TYPES I AND II WASTE TANKS (U)
B. J. Wiersma
R. L. Sindelar

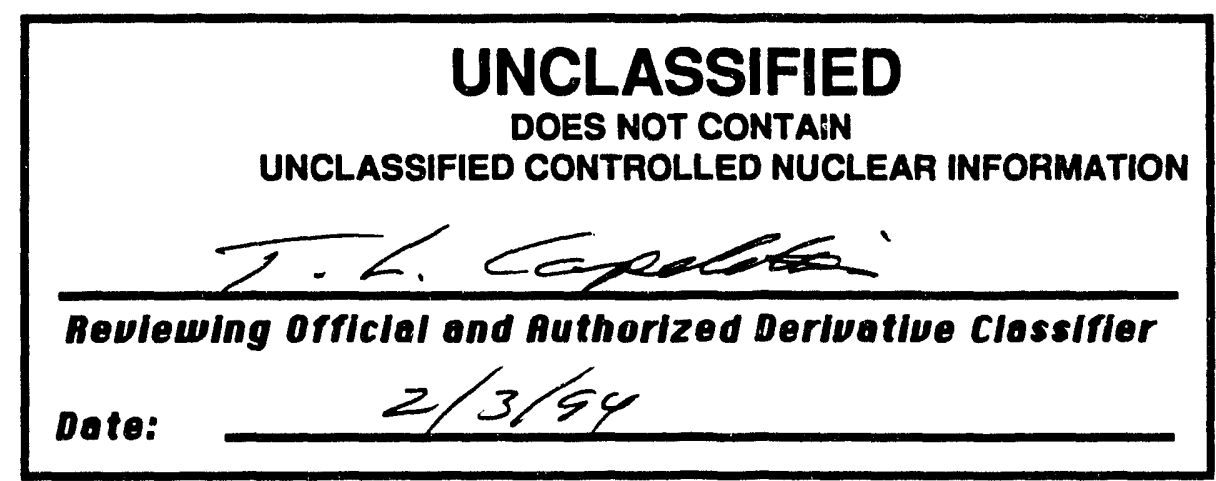

Patent Status:

This internal management roport is being transmifted without DOE patent clearance, and no further dissomination or publication shall be made of the report without prior approval of the DOE-SR patent counsel.

Westinghouse Savannah River Company Savannah River Site Aiken, SC 29808

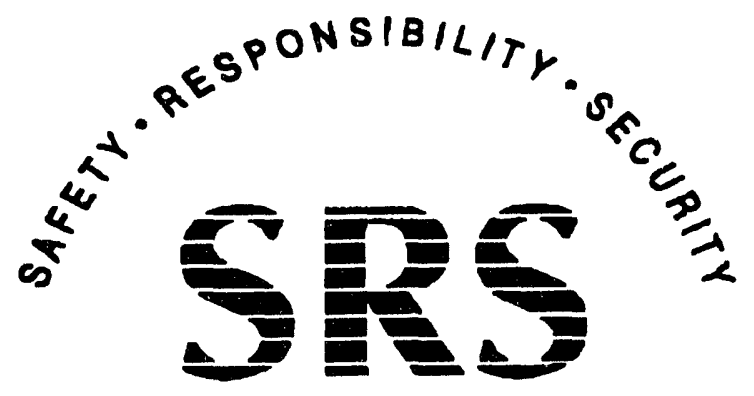

SAVANNAH RIVER SITE

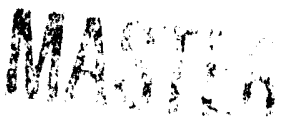


!

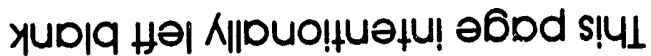




\section{TABLE OF CONTENTS}

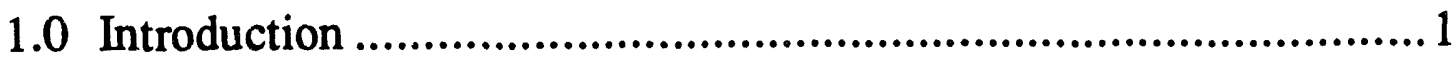

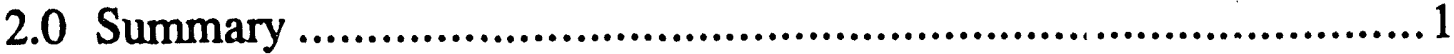

3.0 Discussion ...................................................................... 2

3.1 Tank History ............................................................. 2

3.2 Mechanism of Nitrate Stress Corrosion Cracking ..................2

3.3 Chemistry Control of Nitrate Stress Corrosion Cracking........ 2

3.4 Inspections of Type I and II Waste Tanks ............................ 3

3.5 Statistical Analysis of Crack Sizes ....................................... 3

3.6 Reference Flaw for Structural Analysis .............................4

4.0 Options for Additional Analyses ..............................................4 4

4.1 Collection of Additional Flaw Size Data ............................4

4.2 Evaluation of Residual Stress Distribution .......................... 4

5.0 References..................................................................... 4

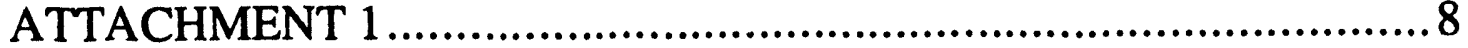

\section{LIST OF FIGURES}

Figure 1. Residual stresses in a carbon steel butt weld. .......................6

Figure 2. Salt deposits on the wall of Tank 16 ................................6 6

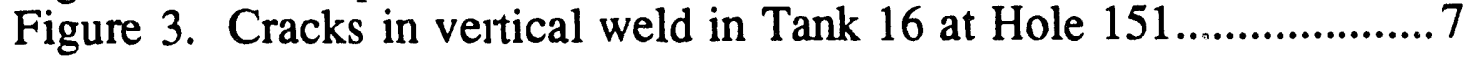




\section{APPROVALS}

Bmee f. Afinsma
B. J. Wiersma, AUTHOR
Materials Applications \& Corrosion Technology Group
MATERIALS TECHNOLOGY SECTION

RZ Hindelar Date: $1-31-94$

R. L. Sindelar, Author

Materials Applications \& Corrosion Technology Group

MATERIALS TECHNOLOGY SECTION

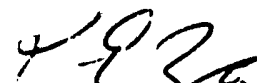

P. E. Zapp. JECHNTCAL REVIEWER

Date: $2-3-94$

Materials Applications \& Corrosion Technology Group

MATERIALS TECHNOLOGY SECTION

hatraj $1 \mathrm{y}$

N. C. Iyer, MANAGER

Materials Applications \& Corrosion Technology Group

MATERIALS TECHNOLOGY SECTION

Date: $2 / 3 / 94$

T- KC Canders

T. L. Capeletti, MANAGER

MATERIALS TECHNOLOGY SECTION

\section{Tequem}

J. E. Marra, Level 4 MANAGER

Technical Support Group

HIGH LEVEL WASTE ENGINEERING

M Chandlen

J, R. Chandler, LEVEL 5 MANAGER

Téchnical Support Group

HIGH LEVEL WASTE ENGINEERING
Date:

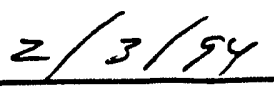

Date: $2 / 4 / 94$

Date:

$2 / 1 / 54$ 
WSRC-TR-94-041

This page intentionally left blank 


\title{
Reference Flaw Size for Structural and Fracture Analysis of Types L and II
} Waste Tanks (U)

\author{
B. J. Wiersma \\ and \\ R. L. Sindelar
}

\section{Introduction}

High Level Waste Engineering (HLWE) is reviewing the Technical Standard requirements for tank level and minimum wall temperature. ${ }^{1}$ These requirements are necessary to minimize the probability of brittle fracture of the primary liner due to normal operating and/or seismic loads. The review includes the determination of a reference flaw size, a maximum through-wall crack length, which may reasonably be applied to structural and fracture analysis of the Type I and II waste tank primary liners. This memorandum briefly discusses the mechanism of crack initiation and propagation, the inspections of primary wall cracks, and a statistical analysis of the measured crack lengths. Recommendations on additional analyses which may increase the confidence in the reference flaw size will also be presented.

The primary liner for Type I and II waste tanks is fabricated from ASTM A285, Grade B carbon steel (A285). The liner received no heat treatments to relieve residual stresses in the heat affected zones. Five Type I waste tanks and all four Type II waste tanks developed through-wall cracks. Leaks developed in tanks 9,10,14 and 16 within less than two years. ${ }^{2}$ Small surface cracks were also observed on the interior of the tank primary. The cracks were perpendicular to the butt welds and extended through the heat affected zone before stopping shortly after penetrating the base metal.

The largest leakage of radioactive waste, approximately 185,000 gallons from the primary into the annulus, occurred from Tank 16, a Type II waste tank. During inspections of this tank over 300 leaks were discovered with the longest observed crack being approximately 6 inches. ${ }^{3}$ Due to the large number of observed cracks and the amount of leakage, this was the only tank that was surveyed for crack lengths. For this analysis, Tank 16 will be considered representative of all Type I and II waste tanks because the materials, construction practices, and tank chemistry represented a worst case.

\subsection{Summary}

The reference flaw size, a maximum through-wall crack length, for structural and fracture analysis of Types I and II waste tanks is 6 inches. This size is the length of the largest observed crack in Type II waste Tank 16. This tank is considered to be the worst case with the largest number of cracks and greatest amount of leakage.

Cracks occurred in Types I and II trunks while in service due to nitrate stress corrosion cracking. Based on an understanding of this mechanism, the short range of the residual stresses in the weld zone, the chemistry control which has been instituted to prevent the initiation and propagation of cracks, and the inspection data, a 6 inch reference flaw is reasonable. Further confidence in this number may be gained by measuring more cracks to obtain a better statistical sample or performing experiments which characterize the residual stresses near the weld. 


\subsection{Discussion}

\subsection{Tank_History}

Tank 16 was placed in service during May 1959 as a receiver of fresh HM process waste. Leaks were detected along the bottom horizontal weld as early as November 1959. The tank was filled to capacity (303 inches) by May of 1960 and remained in this state until September 1960 when approximately half of the waste was transferred to other tanks due to excessive leakage into the annulus. Dehumidifiers were installed into the tank annulus in 1965. The dry air sealed the leaks with salt deposits; therefore in 1967 transfers of low level waste and a blend of high level waste and evaporator bottoms into Tank 16 were initiated. Transfers ceased in March 1972 when excess leakage occurred again. All but 68,000 gallons of the waste was transferred to Tank 13.4 After sludge removal operations, the tank was removed from service in 1980.2

\section{2_ Mechanism of Nitrate_Stress Corrosion_Cracking}

Research 5 and trepanned specimens from the tank ${ }^{6}$ demonstrated that the cracks were due to nitrate SCC. For nitrate SCC to occur a tensile stress and a corrosive medium must be present. Cracks propagate along the grain boundaries of a material as the tensile stress maintains a crevice in which the solution remains aggressive towards the metal. The chemistry of the solution at the crack tip is significantly different from the composition of the bulk solution.

The working and reaction stresses in the waste tank structure were designed to be low; thus the likely source of the tensile stress is the residual stress at the butt welds. Laboratory tests demonstrated that as-welded material immersed in simulated HM process and H-Purex waste was susceptible to nitrate SCC. However, material which had been stress relieved showed no evidence of SCC in these same solutions. ${ }^{5}$ Figure 1 shows that the residual stresses within 1-2 inches of a butt weld in a mild steel may exceed the yield strength of A285 (approximately $30 \mathrm{ksi}$ ). ${ }^{7}$ Since the longest observed cracks extended $2-3$ inches on either side of the weld, and the majority of cracks were 1 inch or less on either side of the weld, ${ }^{3}$ confirmation that the residual stresses provide a driving force for crack propagation seems likely. The Type III waste tanks were stress relieved to eliminate the residual stresses.

The waste solutions contain anions which can both cause or inhibit stress corrosion cracking. Nitrate or hydroxide may initiate SCC, however, the presence of either will inhibit cracking by the other. Nitrite which is present in the waste will also inhibit cracking. ${ }^{8}$ Electrochemical polarization studies show that carbon steels are susceptible to nitrate SCC in potential ranges between -0.3 to $1.1 \mathrm{~V}$ vs. a saturated calomel electrode, while hydroxide SCC occurs at potentials between -0.8 to $-1.0 \mathrm{~V} .{ }^{9}$ In addition hydroxide SCC only occurs at temperatures in excess of $100^{\circ} \mathrm{C}$, whereas nitrate SCC may occur at lower temperatures. ${ }^{10}$ Given that the open-circuit potential measured in several waste tanks is between -0.44 to $-0.064 \mathrm{~V}^{8}$ and the temperature of the waste is generally less than 100 ${ }^{\circ} \mathrm{C}$, the observed cracking is caused by the nitrate.

\subsection{Chemistry Control of Nitrate_Stress Corrosion Cracking}

For tanks which are not stress relieved, controls on the solution chemistry were instituted to preclude the initiation and the further propagation of SCC in these tanks. Two statistically designed sets of experiments were performed to establish inhibitor 
requirements. Impressed current tensile tests examined the amount of inhibitor and temperarure required to prevent the initiation of cracks at different nitrate concentrations. ${ }^{9}$ Modified wedge opening loaded (WOL) specimens with a fatigue pre-crack were used to determine effective stress intensity factor $\left(\mathrm{K}_{\mathrm{SCC}}\right)$ and crack growth rate in $5 \mathrm{M}$ nitrate solutions with varying inhibitor concentrations. ${ }^{11}$

The impressed current tensile tests demonstrated that crack initiation time decreases with increasing nitrate concentration and temperature. Nitrite and hydroxide were shown to inhibit crack initiation. 9 The WOL tests showed that the crack growth rate and $\mathrm{K}_{\mathrm{SCC}}$ were independent of the bulk nitrate concentration. The initiation times for crack growth did depend on the bulk nitrate concentration. This result provides further evidence that the solution chemistry at the crack tip, not the bulk solution chemistry, controls crack growth. Nitrite and hydroxide were shown to prevent crack initiation and propagation at the fatigue pre-crack? A combination of both these inhibitors was shown to be the most effective means of inhibition. The nitrite and hydroxide concentrations for the technical standards limits when the nitrate concentration is above $1 \mathrm{M}$ were based on these tests. These standards were not in effect during the operation of Tank 16.

\subsection{Inspections of Type L and II Waste Tanks}

Tank 16 was inspected extensively twice for leaks. In 1961-62 approximately $73 \%$ of the tank wall was inspected by a television camera and periscope. Salt deposits tailing downward from well-defined spots indicated the positions of leaks (see Figure 2). Approximately 134 leak sites were identified. The cracks at a vertical weld below Hole 151 and between 150-270 inches above the tank bottom were measured by dye penetrant testing (see Figure 3). Ten cracks were measured, with 4 cracks between 4 to 6 inches long. 3

The inspection was repeated in 1972 following the transfer of the waste. This survey indicated that the tank wall had an estimated 350 leak sites. The salt deposits on the walls were also thicker than observed during the earlier inspection (see Figure 4). This enlargement was attributed to seepage of waste between 1960-65 when the dehumidifiers were not in operation or slow seepage between 1961-72. The cracks below Hole 151 were measured again by dye penetrant testing. Thirteen cracks were identified; however, four of the cracks were nearly contiguous and could be pooled as one crack. The cracks had not grown since the 1961-62 measurements. ${ }^{12}$

\subsection{Statistical_Analvsis of Crack_Sizes}

There have been two statistical analyses of the crack size data. In 1979, Wheeler examined the thirteen data points with log-normal probability plots. ${ }^{12}$ The plots estimated that $95 \%$ of the cracks were less than 5 inches. He also claimed, with $90 \%$ confidence, that $95 \%$ of the cracks will be less than 9.4 inches. In 1993, Harris reviewed this analysis (see attachment 1). He concurred with the analytical approach and the 9-inch estimate for the maximum crack size if the sample number is thirteen. Additional calculations showed that if the four cracks were pooled, and the sample number became ten cracks, the maximum crack size would increase to 19 inches. This latter increase shows the effect of decreasing the sample size as well as increasing the average crack length and larger standard deviation. Both analyses acknowledged that the small number of data points probably does not give a full description of the crack population of the tank wall. 


\subsection{Reference Flaw for Structural Analysis}

The structural analysis that was performed to determine the tank fill limits assumed that the reference flaw size was 6 inches. ${ }^{13}$ Based on the above review of the SCC mechanism and the inspection data this reference flaw size is reasonable for the following reasons:

- Laboratory and inspection observations show that the cracks grow perpendicular to the weld for a short distance and then stop. Cracks stop growing as a result of the rapid decrease of the residual stress with distance from the weld. The residual stresses in butt welds of carbon steel are greater than the yield stress in a zone 1 to 2 inches on either side of the weld. This result correlates with the crack length measurements which show that the longest cracks extend 2 to 3 inches on either side of the weld. The majority of cracks measured were 1 inch or less.

- Chemistry controls in place since 1977 inhibit the initiation and further propagation of cracks. Inspections of the tank wall and the annulus indicate that no cracks have initiated since chemistry controls were instituted. ${ }^{2}$

The statistical analysis can not account for the mechanism which may put an upper bound limit on the crack length. The small number of data points available does not allow for an adequate description of the crack size population.

Unless further analyses are done the reference flaw size should remain at 6 inches.

\subsection{Options for Additional Analyses}

\subsection{Collection of Additional Elaw Size Data}

More crack length data will increase the confidence in the estimate for the maximum reference flaw size. Harris estimated the upper tolerance limits for different sample numbers assuming the same distribution parameters (i.e., log-normal, average, standard deviation). Increasing the sample size to 50 would then give $90 \%$ confidence that $95 \%$ of the cracks are less than 6 inches. If more data is to be obtained, in addition to measuring cracks at other welds in Tank 16, crack size data from other tanks should be considered. Further consultation with Harris is recommended to determine an appropriate sample.

\subsection{Evaluation of Residual_Stress Distribution}

One of the bases for assigning a six inch reference flaw is that a driving force for the mechanism, the residual stresses in the weld heat affected zone, decreases significantly with distance from the weld bead. More confidence can be gained in this assertion if experiments which characterize the residual stress distribution in the heat affected zone of tank material are performed.

\subsection{References}

1. M. S. Shurrab to J. E. Marra, "Preliminary Action Plan: Fill Limits and NDTT Concerns for Type I \& II Waste Tanks (Open Technical Issue HLE-TI-93-042)", HLW-HLE-93-1381, December 14, 1993.

2. F. G. McNatt, "Annual Radioactive Waste Tank Inspection Program - 1992 (U)", WSRC-TR-93-166. 
3. W. L. Poe, "Leakage from Waste Tank 16 - Amount, Fate, and Impact", DP-1358, November, 1974.

4. T. L. Davis, D. W. Tharin, D. W. Jones and D. R. Lohr, "History of Waste Tank 16 - 1959 through 1974", DPSPU-77-11-17, July 1977.

5. M. L. Holzworth, L. P. Costas, and W. C. Rion, "Stress Corrosion Cracking of Carbon Steel in Simulated Waste Solution", DP-1023, 1966.

6. R. M. Girdler, " Leaks in Radioactive Waste Tanks", DP-990, December, 1965.

7. W. J. Nordell and W. J. Hall, "Two -Stage Fracturing in Welded Mild Steel Plates", Welding J., Res. Suppl., 44, 1245, 1965.

8. J. A. Donovan, "Materials Aspects of SRP Waste Storage - Corrosion and Mechanical Failure", DP-1476, November 1977.

9. R. S. Ondrejcin, "A Stress Corrosion Cracking Test with Slow Strain Rate and Constant Current", Presented at the ASTM Symposium on Stress Corrosion Cracking, Toronto, Canada, May 1977.

10. H. Mazille and H. Uhlig, " Effect of Temperature and Some Inhibitors on Stress Corrosion Cracking of Carbon Steels in Nitrate and Alkaline Solutions", Corrosion, 28, 427, 1972.

11. J. A. Donovan, "Factors Controlling Nitrate Cracking of Mild Steel", Proc. Conf. Environmental Degradation of Engineering Materials, Blacksburg, VA, October 1977.

12. R. E. Wheeler to R. S. Ondrejcin, " Waste Tank Weld Crack Length", October 1, 1979.

13. W. W. F. Yau to J. M. Boswell, "Analysis of Ductile Fracture and Its Application to 200-Area Waste Tanks", DPST-74-558, January 1975. 
Page 6 of 8

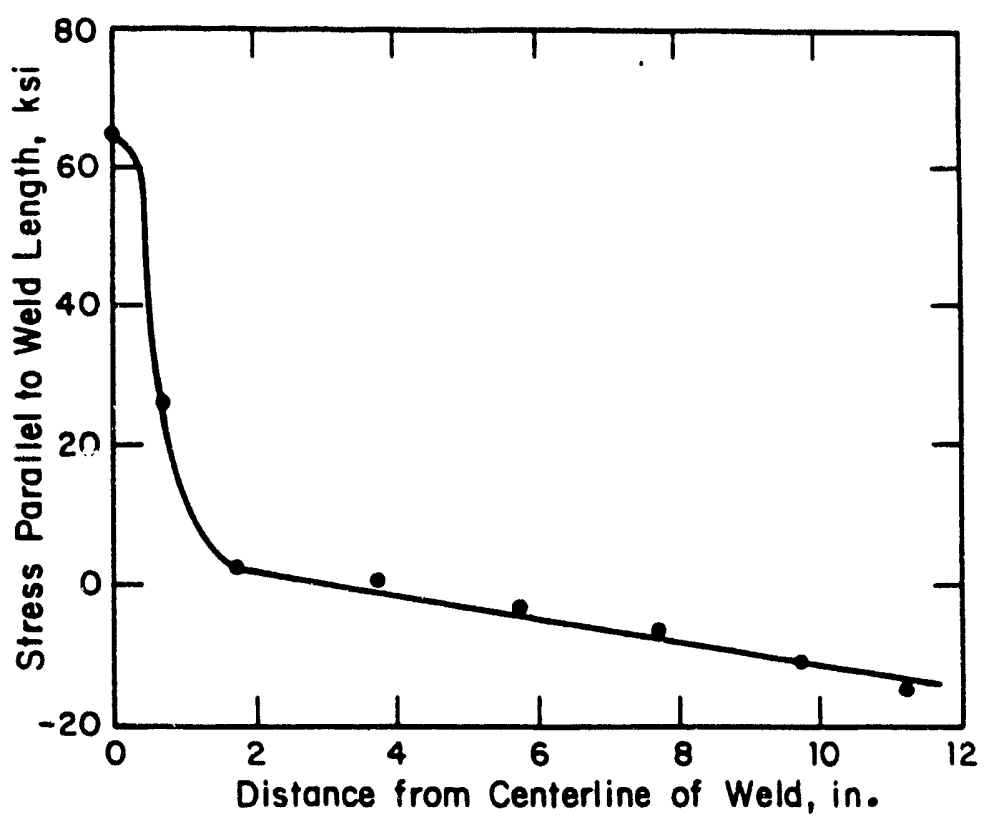

Figure 1. Residual stresses in a carbon steel butt weld.



Figure 2. Salt deposits on the wall of Tank 16 


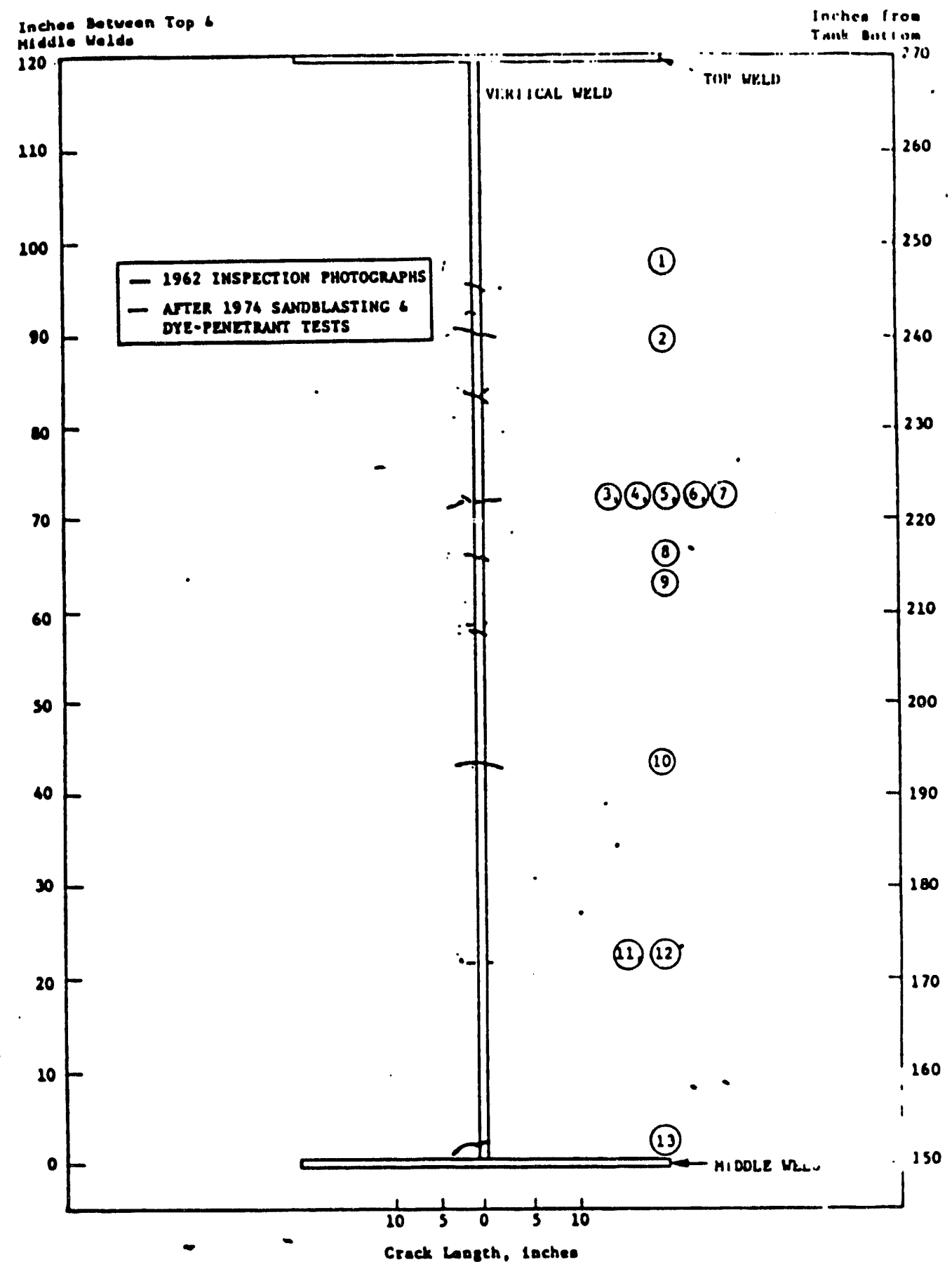

Figure 3. Cracks in vertical weld in Tank 16 at Hole 151. 
L

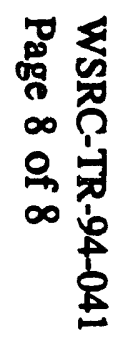

2 
8RT-ASG-930094

December 27, 1993

To: Bob sindelar, 773-41A

Bruce J. Wiersma, 773-A

cc: N.C. Iyer, 773-A

R.C. Tuckfield, 773-42A

E.P. Shine, 773-42A

M.R. Buckner, 773-42A

From: s.P. Harris, 992m-1

ANALY8IB OF TASTE TANR 16 CRACR DATA (O)

I have analyzed the Tank 16 crack length data in the report you supplied dated $10 / 1 / 79$ by R.E. Wheeler, statistical consultant to SRL from commercial E.I. DuPont at that time. Wheeler's report contains the length, in inches, of $N=13$ cracks (APPENDIX 1 ) and the results of his statistical analysis.

The conclusion reached in his report was that the 95th percentile was about 5 inches and that a "conservative" estimate ( $90 \%$ confidence) taking into account the statistical uncertainties is about 9 inches. I find this result to be accurate for the data based on the $\mathrm{N}=13$ cracks. Wheeler also recognizes that it was undetermined if cracks 3 through $6(1.7,0.3,1.1$, and 1.4 inches) were four separate cracks or in fact one large crack of 5.8 inches. However, he did not believe that there was an important difference between these two scenarios as revealed by his graphical analysis. To the contrary, I believe that the difference needs to be considered. Suppose we have one large crack, for cracks 3 through 6 , giving rise to $N=10$ measurements. The estimate of the $95 \mathrm{th}$ percentile is about 7 inches with a "conservative" length being 19 inches with $90 \%$ confidence.

I doubt if this possibility leaves you with a satisfactory feeling. Additional sampling needs to be done to improve the "conservative" estimate. This report is intended to serve as a guide for determining the amount of additional sampling required. Please consult with me on the statistical considerations for selecting the new sample.

\section{BACRGROUND}

You mentioned Wheeler's report is the only record of accurately sized cracks from a single weldment region of Tank 16. Also, you believe the region to be typical of the remaining weldment regions of Tank 16 and that Tank 16 was 
the "worst" cracked tank of the Types I and II tanks. Tank 16 is known to have leaked excessively and to have over 300 salt deposits, from through-wall flaws, on the outside of the primary tank. Tank 16 is not in service.

Wheeler recognizes, and I agree, that the small number of observations probably does not give rise to a "good a description" of the crack length population for Tank 16.

\section{ANALYSIB}

Inspection of the probability plots ( PLOTS 1 and 2 ) from STATGRAPHICS ${ }^{1}$ indicates that the $\log ($ Natural $\log$ ) of the crack length data could reasonably have come from a normal distribution. The Shapiro-Wilk goodness-of-fit statistic, $w$, in CHART 1 , calculated using SAs ${ }^{2}$, gives the same indication. In other words, the crack lengths (inches) can be modeled by a lognormal distribution. The sample statistics are shown in CHART 1 and the percentile estimates in TABLE 1 for the $N=13$ and $N=10$ scenarios.

TABLE 2 contains the upper tolerance limits ${ }^{3}$ for the 95 th percentile for crack. lengths based on varying levels of confidence. From it, a "conservative" estimate which corresponds to $90 \%$ confidence can be selected. As a result, we obtain 8.86 inches for $N=13$ and 18.77 inches for $\mathrm{N}=10$.

TABLES 3 and 4 contain the upper tolerance limits for the 95 th percentile for crack lengths based on hypothetically varying sample sizes with the estimates of the distributional parameters taken from the $\mathrm{N}=13$ and $\mathrm{N}=10$ scenarios, respectively. We can judge the effect of increased sample sizes on lowering the estimates of the upper tolerance limit from the tables. Suppose we sampled 50 cracks and calculated the sample statistics as mean $=0.1094$ and std deviation $=0.8627$ using the $\mathrm{N}=13$ scenario ( TABLE 3 ). We would have $90 \%$ confidence that the 95th percentile for the crack length distribution less than or equal to 6.08 inches in comparison to 8.86 inches for $\mathrm{N}=13$. The table is only meant to yield ball park indications since the estimates for the mean and standard deviation will change and naturally improve as the sample size increases.

1 STATGRAPHICS, Ver. 6: statistical software for the IBM -PC \& compatibles from Manugistics, Inc., Rockville, Md.

2 PC-SAS, Rel. 6.04, SAS Institute, Cary, N.C.

3 UPPER TOLERANCE LIMIT = AVERAGE + $K$ ( STD DEVIATION ) where $K$ is tabulated in ODEH, R.E. AND OWEN, D.B. (1980), TABLES FOR NORMAL TOLERANCE LIMITS, SAMPLING PLANS, AND SCREENING, MARCEL DEKKER, InC. 


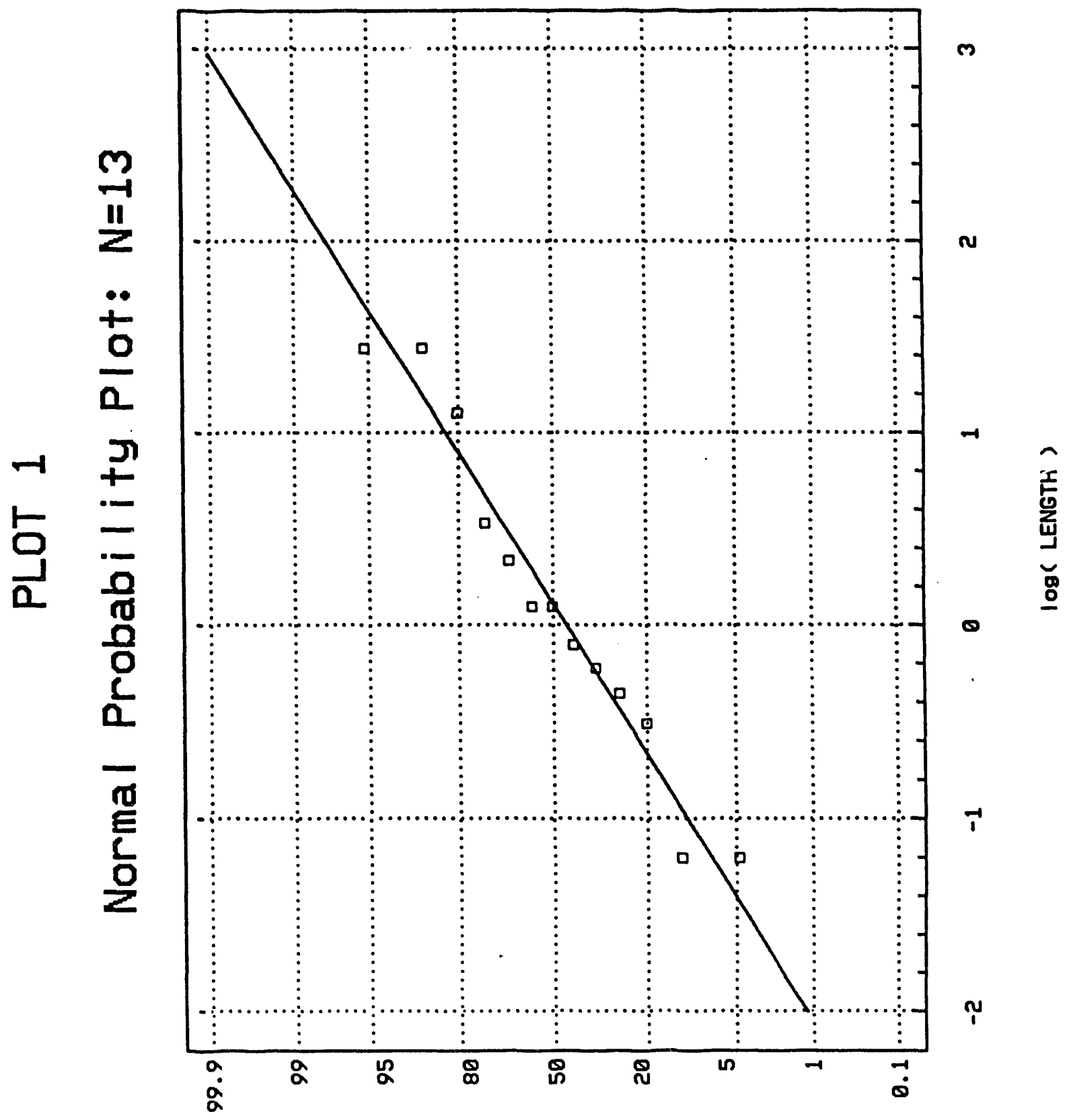

tuasjad an!feinuno 


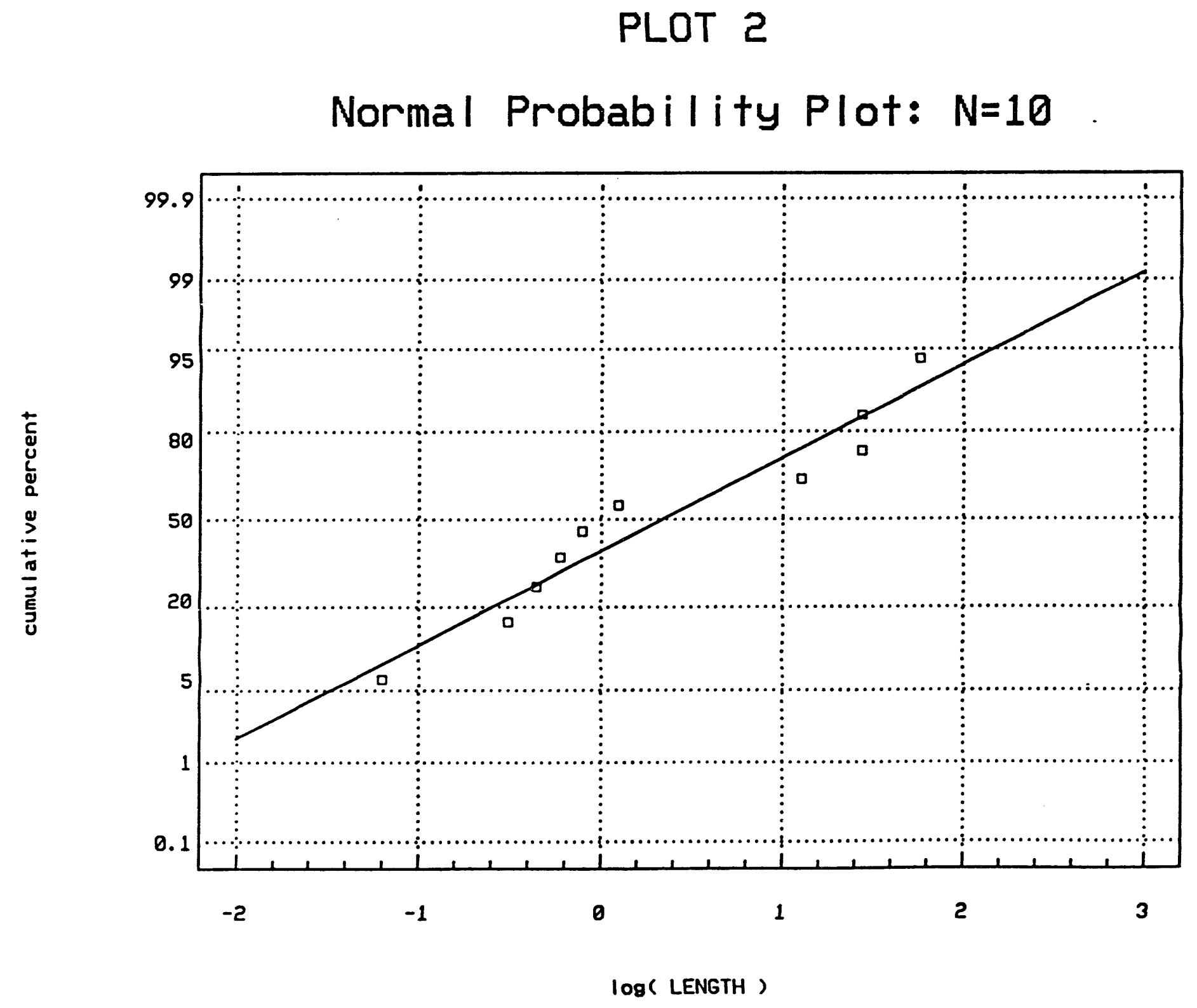




\section{CHART 1}

BTATISTICS FOR LOG ( LENGTH )

$\underline{N=13 \quad \underline{N}=10}$

$\begin{array}{rll}\text { AVERAGE } & 0.1094 & 0.3422 \\ \text { STD DEVIATION } & 0.8627 & 1.0084 \\ \text { Shapiro-Wilk: } & 0.946 & 0.918 \\ \text { Prob<W } & 0.51 & 0.327\end{array}$

( From STATGRAPHICS)

TABLE 1

PERCENTILE ESTIMATES FOR CRACK LENGTHS ASSUMING A LOGNORMAL DISTRIBUTION

PERCENTILE

99 th

95 th

$90 \mathrm{th}$

85 th

75 th

50 th

( FrOm STATGRAPHICS )
$\underline{N=13}$

$\underline{N}=10$

8.30 inches

14.71 inches

4.61

7.40

3.37

5.13

2.73

4.00

2.00

2.78

1.12

1.41 
ONE- 8IDED OPPER TOLERANCE IIMITS FOR THE 95th PERCENTILE AS8UMING NORMALITY FOR THE LOG ( LENGTH ) DATA

$\begin{array}{lcc}\text { CONFIDENCE } & \text { 95th PERCENTILE } & \text { 95th PERCENTILE } \\ & (\mathrm{N}=13) & (\mathrm{N}=10) \\ 95 \% & 11.17 & 26.52 \\ 90 \% & 8.86 & 18.77 \\ 85 \% & 7.71 & 15.31 \\ 80 \% & 6.96 & 13.21 \\ 75 \% & 6.41 & 11.75\end{array}$

$1 \operatorname{ExP}(0.1094+K * 0.8627)$

$2 \operatorname{Exp}(0.3422+\mathrm{K} * 1.0084)$

ODEH, R.E. AND OWEN, D.B. (1980), TABLES FOR NORKAL TOLERANCE IIMITS, SAYPLING PLANS, AND SCREENING, MARCEL DERKER, InC.

( From STATGRAPHICS ) 


\section{TABLE 3}

\section{( $N=13$ SCENARIO )}

ANALYSIS OF VARYING NUMBER OF MEASUREKENTS ( NUMBER ) FOR A NEW SAMPLE.

UPPER TOLERANCE IIMITS FOR THE 95th PERCENTILE ASSUMING NORMALITY FOR THE LOG ( IENGTH ) DATA

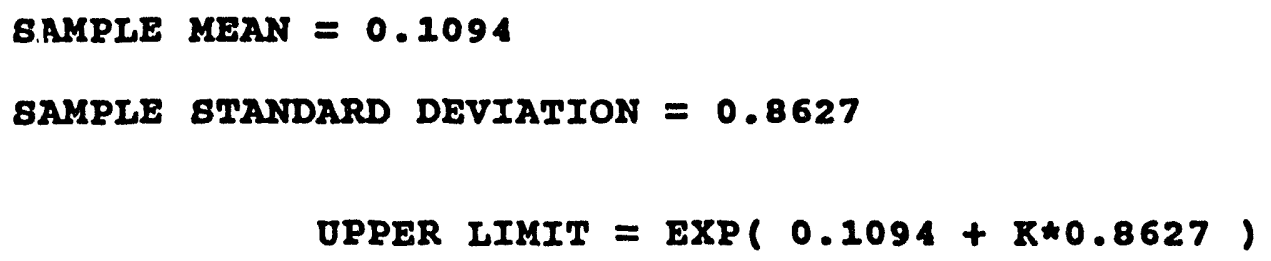

8.57

6.98

6.32

5.43

50

7.90

6.63

6.08

5.32

75

7.02

6.14

5.74

5.17

100

6.57

5.88

5.56

5.08

150

6.11

5.60

5.35

4.98

200

5.86

5.44

5.24

4.93

300

5.59

5.27

5.11

4.87

400

5.44

5.17

5.04

4.83

500

5.34

5.11

4.99

4.81

1000

5.10

4.95

4.87

4.74

999999

4.61

4.61

4.61

4.61

( FrOm SAS APPENDIX 2 PROGRAM ) 
TABLE 4

( $N=10$ BCENARIO $)$

ANALYSIS OF VARYING NOMBER OF MEABUREMENT ( NUMBER ) FOR A NEW GAMPLE.

UPPER TOLERANCE LIMIT FOR THE 95 th PERCENTILE ASSUMING NORMALITY FOR THE LOG ( LENGTH) DATA

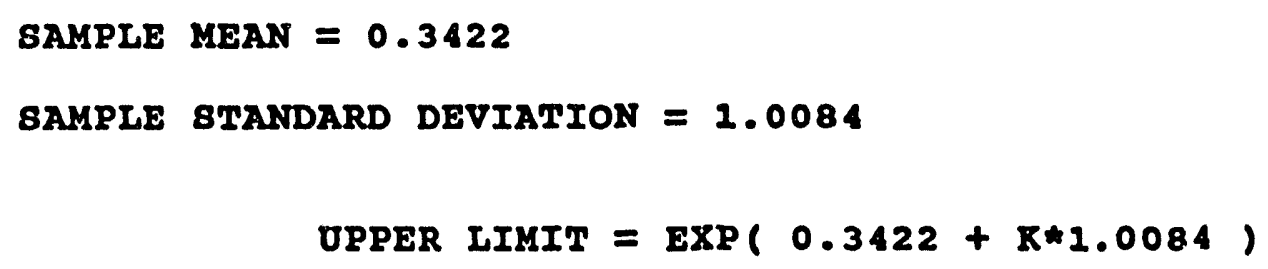

$\begin{array}{rcccc}\text { NUMBER } & 99 \% & 95 \% & 90 \% & \underline{75 \%} \\ 10 & 61.04 & 26.51 & 18.76 & 11.75 \\ 20 & 23.90 & 15.77 & 13.05 & 9.19 \\ 30 & 17.78 & 13.21 & 11.47 & 9.27 \\ 40 & 15.27 & 12.00 & 1.0 .69 & 8.95 \\ 50 & 13.88 & 11.30 & 10.21 & 8.74 \\ 75 & 12.09 & 10.33 & 9.56 & 8.45 \\ 100 & 11.20 & 9.83 & 9.20 & 8.29 \\ 150 & 10.28 & 9.28 & 8.81 & 8.10 \\ 200 & 9.79 & 8.98 & 8.59 & 8.00 \\ 300 & 9.26 & 8.65 & 8.35 & 7.88 \\ 400 & 8.97 & 8.46 & 8.21 & 7.81 \\ 500 & 8.77 & 8.33 & 8.11 & 7.76 \\ 1000 & 8.32 & 8.03 & 7.89 & 7.65 \\ 999999 & 7.40 & 7.40 & 7.40 & 7.40\end{array}$




\section{APPENDIX I}

CRACR LENGTH DATA FROM WHEELER'B REPORT DATED OCTOBER 1, 1979

1. 0.7 inches

2. 4.2

3. $1.7 *$

4. $0.3 *$

5. $1.1 *$

6. $1.4 *$

7. 0.6

8. 0.8

9. 0.3

10. 4.2

11. 1.1

12. 0.9

13. 3.0

* Cracks 3. through 6. : 5.8 inches 
PC- SAS, REI. 6.04, PROGRAM FOR CALCULATING TOLERANCE IIMITS IN TABLE 3

R VALUES TAREN FROM ODEH, R.E. AND OWEN, D.B. (1980), TABLES FOR NORMAL TOLERANCE LIMITS, BAMPLING PLANS, AND 8CREENING, MARCEL DERKER, InC.






\section{APPENDIX I}

CRACK LENGTE DATA FROM WHEELER'B REPORT DATED
OCTOBER 1, 1979

$\begin{array}{ll}\text { 1. } & 0.7 \text { inches } \\ \text { 2. } & 4.2 \\ \text { 3. } & 1.7 \text { * } \\ \text { 4. } & 0.3 * \\ \text { 5. } & 1.1 \text { * } \\ \text { 6. } & 1.4 \text { * } \\ \text { 7. } & 0.6 \\ \text { 8. } & 0.8 \\ \text { 9. } & 0.3 \\ 10 . & 4.2 \\ 11 . & 1.1 \\ 12 . & 0.9 \\ 13 . & 3.0\end{array}$

* Cracks 3. through 6.: 5.8 inches 
PC- 8As, REl. 6.04, PROGRAK FOR CALCULATING TOLERANCE LIMITS IN TABLE 3

K VALUES TAKEN FROK ODEE, R.E. AND OWEN, D.B. (2980), TABLES FOR NORYAL TOLERANCB IIXITB, BAYPLING PLANS, AND BCREENING, MARCEL DERLER, InC.

GOPTIONS DEVICE=PS2EGA;

DATA DO :

* P=0.95 FOR AIL, I.E. THE COVERAGE;

INPUT NUMBER K99 K95 K90 K75:

AVERAGE $=0.1094 ;$ STD $=0.8627 ;$ FOR N=13 SCENARIO;

LIM9 9=EXP (AVERAGE + K99*STD) :

LIM95=EXP (AVERAGE + K95*STD) ;

LIM9 O=EXP (AVERAGE + K90*STD);

LIM75=EXP (AVERAGE + K75*STD) :

* K99 IS THE K VALUE WITH $99 \%$ CONFIDENCE;

LIM99=ROUND (LIM99, 0.01):

LIM95=ROUND (LIM95, 0.01):

LIM9 0=ROUND (LIM90,0.01):

LIM75=ROUND (IIM75, 0.01):

\section{CARDS :}

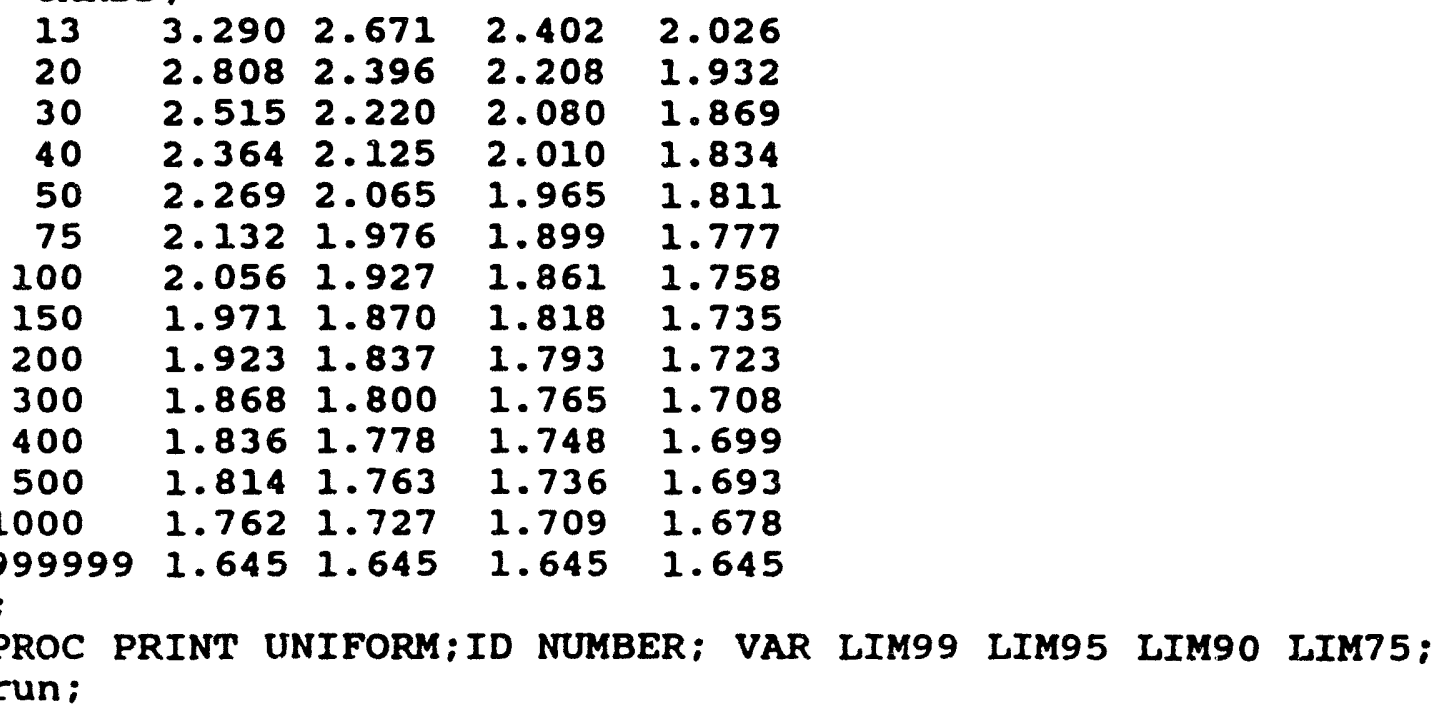




\section{DISTRIBUTION}

\section{Westinghouse Savannah River Company}

T. M. Monahon

V. G. Dickert

W. B. Boore

B. L. Lewis

J. E. Marra

J. R. Chandler

F. G. McNatt, Sr.

J. P. Morin

R. M. Satterfield

G. E. Mertz

M. S. Shurrab

M. E. Maryak

F. Loceff

T. W. Houston

C. D. Cowfer

V. Cech

H. E. Flanders

I. D. Hill

M. W. Loibl

R. Ostrowski

J. D. Cohen

T. L. Capeletti

M. R. Louthan, Jr.

N. C. Iyer

R. L. Sindelar

B. J. Wiersma

SRTC Records

MTS Files

(c/o J. M. Gantz)
703-H

703-H

703-8C

703-8C

703-H

703-H

704-8H

719-4A

719-4A

730-B

707-H

730-B

707-49B

730-B

707-35B

740-11A

707-49B

305-1A

305-1A

707-35B

730-A

773-41A

773-A

773-A

773-41A

773-A

773-52A

773-A 

